\title{
Abrenuncjacja od substancji rodzicielskiej w świetle akt grodzkich przemyskich $z$ lat 1651-1657
}

\author{
Abstract \\ Renunciation of Parental Assets in Light of the Records of the Borough \\ of Przemyśl of 1651-1657
}

The act of abrenunciation (renunciation) was a commonly practiced legal action before the Polish courts for nobles, conducted by a woman upon contracting marriage, or entering a convent. It consisted of acknowledgment receipt of a dowry by the husband or convent, and of the woman's renunciation of any further rights to the family estate. The statement, according to the chancellery standards, was to be presented orally for the record in the court for nobles. The legal effect of abrenunciation was the surrender of any and all further claims to the inheritance against the current owners of the family estate.

Keywords: renunciation, rejections, dowry, family estate

Słowa kluczowe: abrenuncjacja, zrzeczenie, posag, majątek rodzinny

\section{Zagadnienia wstępne}

Problematyka dziedziczenia kobiet i małżeńskiego prawa majątkowego okresu I Rzeczypospolitej wielokrotnie była już przedmiotem badań naukowych ${ }^{1}$. Niewiele

1 Do najważniejszych opracowań poświęconych tym zagadnieniom należą: W. Dutkiewicz, Stowo o stosunkach majątkowych między matżonkami i o prawie zwyczajowym polskim, Warszawa 1877; W. Spasowicz, O stosunkach majątkowych między matżonkami wedle dawnego prawa polskiego [w:] Pisma, t. IV, Petersburg 1892, s. 1-49; A. Winiarz, Polskie prawo dziedziczenia kobiet $w$ wiekach średnich, KH 1896, t. X, s. 756-812; idem, Polskie prawo majątkowe matżeńskie w wiekach średnich, Kraków 1898; S. Matusiak, Wiano i posag, Warszawa 1912; K. Koranyi, Podstawy średniowiecznego prawa spadkowego, Lwów 1930; S. Roman, Stanowisko majątkowe wdowy w średniowiecznym prawie polskim, CPH 1953, t. V, s. 80-108; B. Lesiński, Stanowisko kobiety w polskim prawie ziemskim do połowy XV wieku, Wrocław 1956; J. Adamus, O prawie dziedziczenia nieruchomości przez kobiety w najdawniejszym prawie polskim, CPH 1959, 
uwagi poświęcono jednak jak dotąd zagadnieniu abrenuncjacji ${ }^{2}$ - kluczowej z punktu widzenia spadkobrania czynności prawnej. Polegała ona na rezygnacji z roszczeń majątkowych do dóbr rodziców przez córkę (względnie siostrę) wstępującą w związek małżeński lub składającą śluby zakonne i otrzymującą z tego tytułu wyprawę oraz posag. Abrenuncjacja, związana z przyjętym w polskim prawie ziemskim modelem rządu posagowego, była jego nieodłącznym elementem, na mocy którego kształtowano stosunki majątkowe między wyposażaną kobietą a jej rodziną.

Zgodnie z praktykowanym na ziemiach polskich prawem zwyczajowym, na dzierżących majątek rodzinny krewnych wychodzącej za mąż lub wstępującej do zakonu kobiety ciążył obowiązek jej wyposażenia ${ }^{3} \mathrm{w}$ wysokości stosownej do stanu zamożności osoby zobowiązanej ${ }^{4}$. W przypadku ojca obowiązek ten, zdaniem Alojzego Winiarza, miał jedynie charakter moralny ${ }^{5}$, a o wysokości posagu decydował on według własnego

t. XI, z. 1, s. 125-144; M. Koczerska, Rodzina szlachecka w Polsce późnego średniowiecza, Warszawa 1975; W. Uruszczak, Uwagi o polskiej rodzinie szlacheckiej w późnym średniowieczu, CPH 1976, t. XXVIII, z. 2, s. 249-261.

2 Nad kwestią tą pochylili się na marginesie swoich badań: T. Zielińska, Rozważania nad kwestia wyposażania szlachcianek w Wielkim Księstwie Litewskim w XVIII stuleciu, KH 1989, R. 96, z. 1-2, s. 94-95; A. Penkała, Panieńskie ochędóstwo. Kwestie posagowe $i$ wienne w malżeństwach szlachty województwa krakowskiego w czasach saskich, Kraków 2016, s. 130; oraz badacze tzw. kontraktów lwowskich: M. Wąsowicz, Kontrakty lwowskie w latach 1676-1686, Lwów 1935, s. 84-85, tab. XXX; S. Siegel, Kontrakty lwowskie w latach 1717-1724, Lwów 1935, s. 167-168, tab. XXIX; J. Bielecka, Kontrakty lwowskie w latach 17681775, Poznań 1948, s. 90-91, tab. XXXV. Słowniki łacińskie thumaczą termin abrenuntiatio jako: odwołanie, wyrzeczenie się, zrzeczenie; M. Plezia, Stownik tacińsko-polski, t. I, Warszawa 1959, s. 12; J. Sondel, Stownik tacińsko-polski dla prawników i historyków, Kraków 2005, s. 6. Według słowników języka polskiego słowo „abrenuncjacja” oznaczało „zrzeczenie się przez wyposażoną córkę przyszłego jej spadku”; M. Orgelbrand, Stownik języka polskiego, cz. I, Wilno 1861, s. 4. Z. Gloger zwraca uwagę, że abrenuncjację nazywano też wyrokiem (zob. VL VII, fol. 63), od czynności wyrzeczenia się, Encyklopedia staropolska ilustrowana, t. I, Warszawa 1900, s. 3. Zob. też: I. Szczepankowska, Język prawny I Rzeczypospolitej w „Zbiorze praw sqdowych" Andrzeja Zamoyskiego, t. I, Pojęcia prawne, Białystok 2004, s. 176. W dawnym polskim prawie prywatnym termin ten znany jest również w odniesieniu do tzw. aqua abrenuntiationis - wody zrzeczenia się - symbolicznej czynności dokonywanej przy przenoszeniu własności, zob. J. Matuszewski, Aqua abrenuntiationis. Studium z średniowiecznego prawa prywatnego, CPH 1952, t. IV, s. 164-237.

3 Nie wchodząc głębiej w rozważania na temat genezy zwyczaju wyposażania córek, zasygnalizujmy jedynie, że w literaturze zdecydowanie przeważa pogląd, iż wypłacany kobiecie posag stanowił przysługującą jej po rodzicach część spadkową, zob.: P. Burzyński, Prawo polskie prywatne, t. II, Kraków 1871, s. 136; A. Winiarz, Polskie prawo majątkowe..., s. 1; P. Dąbkowski, Prawo prywatne polskie, t. I, Lwów 1910, s. 387; J. Stachel, Posag jako instytucja prawa spadkowego [w:] Pamiętnik trzydziestolecia pracy naukowej prof. Przemystawa Dąbkowskiego, Lwów 1937, s. 201-204; J. Bardach, Historia państwa i prawa Polski, t. I, Warszawa 1965, s. 286. Poglądu tego nie podzielił B. Lesiński, wskazujący na brak do końca XII wieku źródeł potwierdzających przypadki dziedziczenia kobiet lub wypłacania im posagu w pieniądzu, Stanowisko kobiety..., s. 91. Odmienne stanowisko zajęła także M. Koczerska, której zdaniem posag nie mógł oznaczać części przynależnego kobiecie spadku, skoro po jego otrzymaniu musiała dodatkowo dokonać dalszych czynności zrzeczenia, co byłoby zbędne, gdyby posag ów odpowiadał wartości części spadkowej, Rodzina szlachecka ..., s. 46. Argument M. Koczerskiej odrzucił W. Uruszczak, Uwagi o polskiej rodzinie..., s. 260.

4 A. Winiarz, Polskie prawo dziedziczenia..., s. 20.

5 A. Winiarz, Polskie prawo majątkowe..., s. 3. P. Dąbkowski za W. Maciejowskim podaje, że córka nie miała prawa domagać się posagu za życia ojca, chociażby wychodziła za mąż, a jego wyznaczenie przez rodziców było wyrazem ich łaski wobec córki, Prawo prywatne..., s. 388-389. Podobnie T. Czacki, który twierdzi, że: „dawanie małego posagu zależało od woli ojca”, O litewskich i polskich prawach, o ich duchu, źródłach, związku i o rzeczach zawartych w pierwszem Statucie dla Litwy 1529 roku wydanem, t. II, Warszawa 1801 , s. 6. 
uznania $^{6}$, nierzadko w testamencie ${ }^{7}$. Jeśli ojciec zmarł przed wydaniem córki za mąż, nie wyznaczając jej posagu, zobowiązanie spadało na dziedziczących braci lub pozostałych $\mathrm{krewnych}^{8}$, a wydania posagu kobieta opuszczająca dom rodzinny mogła dochodzić na drodze sądowej ${ }^{9}$.

Wypłata posagu pociągała za sobą obowiązek jego „zakwitowania” - urzędowego poświadczenia przyjęcia otrzymanej sumy ${ }^{10}$. Jednocześnie kobieta zobowiązana była do złożenia formalnego oświadczenia - tak zwanej abrenuncjacji od substancji rodzicielskiej $^{11}$ - o zrzeczeniu się dalszych praw do majątku rodzinnego. Wynikało to z rzeczowego charakteru posagu, obciążającego rodzinny majątek. Kwestia ta została uregulowana już w statutach Kazimierza Wielkiego ${ }^{12}$. Podobne rozwiązanie znane było także na Mazowszu - statut z 1414 r., ex lege pozbawiający wyposażoną przez ojca córkę prawa do majątku rodzicielskiego, zdaniem Karola Dunina, uległ modyfikacji i z czasem odebranie posagu przez kobietę pociągało za sobą obowiązek dokonania formalnego zrzeczenia ${ }^{13}$, czego wyrazem był przepis w Zbiorze Goryńskiego ${ }^{14}$. O obowiązku

6 M. Koczerska, Rodzina szlachecka..., s. 45.

7 B. Popiołek, Rodzina szlachecka w świetle testamentów XVII-XVIII wieku [w:] Rodzina i gospodarstwo domowe na ziemiach polskich w XV-XX wieku. Struktury demograficzne, spoleczne i gospodarcze, red. C. Kuklo, Warszawa 2008, s. 143.

${ }^{8}$ Zob. więcej: P. Burzyński, Prawo polskie ..., s. 136; W. Spasowicz, O stosunkach ..., s. 12-13; P. Dąbkowski, Prawo prywatne..., s. 389-391.

9 Próbę uregulowania tej materii w drodze ustawy podjęli autorzy Korektury Praw z 1532 r., uzależniając wysokość posagu od woli rodziców: Quapropter statuimus, cum aliqua virgo vel puella nuptui traditur, dos competens in pecunia numerata pro arbitrio parentum, eidem constituatur, a po ich śmierci nakładając obowiązek wyposażenia sióstr na braci Ubi vero per parentes in vita quantitas dotis filiabus constituta non est, post mortem fratres [...] de bonis paternis et maternis sororibus, dotem constituant, Statuta inclyti Regni Poloni[a]e recens recognita emendata, wyd. Hieronim Wietor, Kraków 1532, fol. 59. Odrzucenie projektu Korektury spowodowało jednak, że obowiązek ustawowy wyposażenia sióstr wprowadzono dopiero w 1588 r., w drodze konstytucji O posażeniu sióstr (VL II, fol. 1212), w myśl której bracia winni byli wyznaczyć posag ,według zdania i sumienia swego”. Sformułowanie to było bardzo ogólne. Zapewne z tego powodu, jak podaje J. Michalski, postulat szczegółowego uregulowania tej kwestii znalazł się w XVIII-wiecznych instrukcjach sejmikowych, Studia nad reforma sądownictwa i prawa sądowego w XVIII w., Wrocław-Warszawa 1958, s. 245. Przykłady procesów o wypłatę posagu przytacza w swojej monografii A. Penkała, Przeciw prawu, tradycji i obyczajowi. Sprawy procesowe szlacheckich matżéstw w księgach sądów grodzkich z terenu województwa krakowskiego w czasach saskich, Kraków 2017, s. 80-107.

10 Wyraźnie wskazują na to formularze umów, o których szerzej piszemy w dalszej części artykułu: Quia ipsa, generosos parentes illorumque successores de summa N. florenorum polon: dotali, se recognoscentem de bonis paternis \& maternis concernenti; T. Ostrowski, Prawo cywilne albo szczególne narodu polskiego, t. II, Warszawa 1784, s. 284.

11 Sformułowanie to pojawia się m.in. we wspomnianym wyżej formularzu przytoczonym przez T. Ostrowskiego, Prawo cywilne ..., t. II, s. 284. W formularzach litewskich akt ten tytułowany był jako,,zapis zrzeczny kwitacyjny z wyposażenia"; T. Umiastowski, Sądowy proces czyli sposób prawowania się w Trybunale $i$ wszystkich subselliach W. Xięstwa Litewskiego..., wyd. V, Grodno 1782, s. 140-141; A. Korowicki, Proces cywilny litewski, Wilno 1826, s. 287-288.

12 Art. XCIX Statutu Wiślickiego stanowił: Eciam statuimus, dum aliqua domicella maritatur, dos sive donacio in pecunia parata sufficiat, que in presencia amicorum assignetur, Statuty Kazimierza Wielkiego, oprac. O. Balzer, Poznań 1947, s. 511.

13 K. Dunin, Dawne mazowieckie prawo, Warszawa 1880, s. 123.

14 Cum aliquis nobilis filiam suam, aut sororem, aut neptem, vel quamvis aliam consaguineam, viro matrimonialiter condictaverit, et super dote ac paraphernalibus, seu mundo muliebri, necnon dotalitio et abrenunciatione..., Statuta Ducatus Mazoviae [w:] Ius Polonicum codicibus veteribus manuscriptis et editionibus quibusque collatis, wyd. J.W. Bandtkie, Warszawa 1831, s. 392. 
abrenuncjacji wspominają także opracowywane na podstawie praktyki projekty kodyfikacyjne okresu I Rzeczypospolitej, które nie zostały wprowadzone w życie: Korektura Praw z 1532 r. ${ }^{15}$ oraz Zbiór Praw Andrzeja Zamoyskiego z 1778 r. ${ }^{16}$ Instytucja ta miała zresztą znacznie szerszy zasięg i znana była chociażby w sąsiednich Czechach ${ }^{17}$.

Jak ważną rolę odgrywało formalne oświadczenie o abrenuncjacji złożone przed urzędem, dowodzi Maria Koczerska, przywołując zwyczaj ziemi łęczyckiej, w myśl którego zrzeczenie niezapisane w księdze sądowej przedawniało się po 3 latach, a siostra mogła wnosić wówczas swoje pretensje do rodzinnego majątku ${ }^{18}$.

Zeznania abrenuncjacji po otrzymaniu posagu składały również osoby wstępujące do klasztoru. Kwestia ta została uregulowana dwukrotnie, w konstytucjach sejmowych w wieku XVIII. W ustawie $O$ młodzi szlacheckiej do zakonu wstepujacej z 1764 roku wskazywano na nierzadką praktykę, kiedy to kandydaci po odbytym nowicjacie, „a przed uczynioną profesją, częstokroć równego działu substancyi ojczystej i macierzystej uzurpują sobie, i te części na siebie spadłe pro libitu sui sprzedają, i one dysponują". Stąd nakaz, aby „każdy, który już wstąpił i wstępować będzie, po skończonym nowicjacie zaraz wyrok przed aktami grodzkimi czyli ziemskimi któremikolwiek substancyi ojczystej czyli macierzystej [...] czynili”'19. Cztery lata później zasady „ustawy konwokacyjnej 1764 dla płci męskiej” zostały rozciągnięte także na mniszki, z dodatkowym zastrzeżeniem wydawania im wyprawy (expeditio muliebris) wyłącznie w ruchomościach - sprzętach domowych (supellectilis) ${ }^{20}$.

Choć, jak wyżej wspomniano, skutkiem złożenia oświadczenia o abrenuncjacji była utrata praw do rodzinnego majątku, w praktyce wyposażone kobiety często występowały z roszczeniem o podwyższenie posagu ${ }^{21}$, szczególnie w przypadku gdy „rodzice

15 W myśl projektu, po otrzymaniu posagu kobieta omnibus paternis et maternis, de quibus dotatae sunt, cum maritorum suorum consensu, expresse renuntiare tenebuntur. W akcie zrzeczenia winno znaleźć się również oświadczenie o rezygnacji ze spadków po innych krewnych: sorores etiam ad devoluciones post mortem consanguineorum quasqumque, interesse habere non debeant, id in actu renuntiationis nominatim exprimi debet, Statuta inclyti..., fol. $59 \mathrm{v}$.

16 „Córka, którą ojciec za życia wyposażył, jeżeli abrenuncjację z substancyi ojczystej i macierzystej uczyniła, nic od braci więcej z tej substancyi żądać nie powinna”, Zbiór Praw Sądowych na mocy konstytucyi roku 1776 przez J. W. Andrzeia Zamoyskiego ex-kanclerza koronnego, kawalera Orderu Orła Białego ułożony i na seym roku 1778 podany, Warszawa 1778, cz. II, art. XIV, § 12.

17 Czeskie prawo ziemskie wymagało dokonania przed urzędem formalnego aktu zrzeczenia się przez wyposażoną córkę praw do majątku rodzinnego, J. Kapras, Manželské právo majetkové dle českého práva zemského, Praha 1908, s. 23-24.

18 M. Koczerska, Rodzina szlachecka..., s. 52.

19 VL VII, fol. 63.

20 VL VII, fol. 820.

21 „O abrenuncjacjach czyli wyrokach de bonis paternis et maternis, a drudzy czasem podciągają etiam successivis, które wyroki prawem i zwyczajem wsparte vigent do tych czas, a dosyćby przestać na kwicie de dote de bonis paternis et maternis persoluta i obwarowaniu bezpieczeństwa na dobrach dziedzicznych tejże sumie, bo lubo exdotatae wyroki czynią a substantia paterna et materna, jednakże decedentibus iis, po których exdotatas spectat successio, biorą sukcesją i wyrok nie zagradza im drogi do tego ut est quod iure sit juste sit, o tym dysceptować nie można, ale successiones devolvendas faemellias respicientes, pod wyrok pociągać jako nie jest rzecz, która by się mogła zawsze utrzymać, tak takie wyroki częstokroć kasowane bywają", M. Słoński, Accessoria, statut i konstytucye Czaradzkiego, Ładowskiego y suplementu J. O. Xcia Jegomości Biskupa Krakowskiego w Pospolitości a najbardziej co do procesu potrzebniejszego tudzież Formularze tranzakcyi niektórych przez Jmci Pana Michała Słońskiego Vicegerenta Łukowskiego S.G. zebrane, Lwów 1760, s. 649-650; ,Żona posag od rodziców biorąca, czyni od reszty substancyi abrenuncyacyą, [...] 
po wyposażeniu córek, albo przez sukcesję, albo przez kupno, dóbr nabywają"22. Uprawnienie to było jednak nadużywane ${ }^{23}$. Być może dlatego w propozycji zawartej w projekcie A. Zamoyskiego wprowadzono przepis zakazujący wyposażonym siostrom, które dokonały abrenuncjacji, prawa do wystąpienia pro melioratione dotis pod sankcją kary 2000 zł na rzecz pozwanego oraz kary pół roku wieży dla męża lub kuratora takie roszczenie popierającego ${ }^{24}$.

\section{Praktyka abrenuncjacji}

\section{II.1. Badany materiał źródłowy}

Podstawą źródłową badań były oblaty aktów abrenuncjacji zeznanych do ksiąg grodzkich przemyskich w latach 1651-165725. Wyselekcjonowany materiał, choć obejmuje zaledwie kilka lat pracy urzędu starościńskiego ${ }^{26}$, okazał się bogaty $\mathrm{w}$ interesującą nas dokumentację. Pozwoliło to dokonać na jego podstawie wstępnej charakterystyki czynności prawnej zrzeczenia się majątku rodzicielskiego. We wspomnianym okresie

nic jej ta nie szkodzi do czynienia sądownie pro amelioratione dotis", T. Ostrowski, Prawo cywilne...., t. I, s. 188; „Miały [siostry i córki - M. G.] na zwyczaju zasadzoną moc czynić o polepszenie czyli o meliorację posagu, pomimo abrenuncjacyi, jakie zwykle przy intercyzach zachodziły", J.W. Bandtkie, Prawo prywatne polskie napisane $i$ wykladane przed $r .1830 \mathrm{w}$ b. Warszawskim Aleksandryjskim Uniwersytecie, Warszawa 1851, s. 342. Por. P. Burzyński, Prawo polskie..., s. 248.

${ }_{22}$ T. Ostrowski, Prawo cywilne...., t. I, s. 170.

23 Dowodzi tego przypadek rozpatrywany przez Radę Nieustającą, która zapytana o prawo do wystąpienia wyposażonych przez ojca córek z roszczeniem majątkowym do nabywcy i aktualnego posiadacza dóbr rodzinnych, pomimo dokonanej wcześniej abrenuncjacji, odpowiedziała negatywnie i powołując się na wcześniejsze prawa, stwierdziła, że wyposażone siostry „swym posagiem kontentować się powinny”, Rezolucja nr 309 z 26. 9. 1788 r., Zbiór rezolucji interpretacyjnych Rady Nieustającej z lat 1786-1788, oprac. M. Głuszak, Łódź 2014, s. 289-290.

${ }^{24}$ Zbiór Praw..., cz. II, art. XIV, § 15. Rozwiązanie zaproponowane w tym przepisie skrytykował W. Dutkiewicz. Przywołując $\S 1$ artykułu XIV, gwarantujący każdej siostrze 1/3 wartości schedy odziedziczonej przez każdego brata, zarzucił autorom projektu, że w przypadku błędnej wyceny ojcowskich dóbr $\mathrm{i}$ intrat, np. na podstawie niedokładnych rejestrów, siostrom, które dokonały abrenuncjacji, w razie ponownego, prawidłowego oszacowania majątku, nie przysługiwałoby już prawo do roszczenia o meliorację posagu, Zbiór Praw Sądowych przez ex-kanclerza Andrzeja Ordynata Zamoyskiego ułożony i w roku 1778 drukiem ogtoszony, a teraz przedrukowany, z domieszczeniem źródet i uwag tak prawoznawczych jak i prawodawczych, sporzadzonych przez Walentego Dutkiewicza, Warszawa 1874, s. 341.

${ }_{25}$ Wybór ten podyktowany był dostępnością ksiąg. Rękopisy akt grodu przemyskiego ze wspomnianego okresu znajdują się w Centralnym Państwowym Archiwum Historycznym Ukrainy (dalej: CPAHU) we Lwowie, zespół 13, op. 1. Dostępne są również w formie cyfrowej w Repozytorium Cyfrowym Poloników na stronie http://www.repcyfr.pl/dlibra. (dostęp: 20.04.2018), z którego korzystaliśmy, prowadząc powyższe badania. Niestety, należy w tym miejscu podkreślić, że pomimo niewątpliwego ułatwienia, jakie przyniosło opracowanie cyfrowe ksiąg grodzkich przemyskich (możliwość wyszukiwania konkretnego dokumentu pod kątem rodzaju aktu, daty, nazwisk i imion osób w nim wymienionych), ich opisy zawierają sporo błędów, co wymaga od badacza zachowania szczególnej ostrożności.

26 Starostą sądowym grodu przemyskiego w latach 1650-1667 był Marcin Madaliński, J. Seredyka, Madaliński Marcin, PSB, t. XIX, Kraków 1974, s. 111-112; Urzędnicy województwa ruskiego XIV-XVIII wieku. Spisy, oprac. K. Przyboś, red. A. Gąsiorowski, Kórnik 1987, s. 238-239. 
odnotowaliśmy 47 aktów abrenuncjacji, co daje w przybliżeniu średnią 8 aktów na rok ${ }^{27}$. Zeznania te nie należały zatem do rzadkich, a wspomniany materiał może być reprezentatywny dla omawianej instytucji.

\section{II.2. Charakterystyka aktów zrzeczenia się praw do majątku rodziców}

Akty abrenuncjacji w badanych księgach przemyskich były spisywane na podstawie specjalnych formularzy umów powszechnie stosowanych w I Rzeczypospolitej w kancelariach ziemskich i grodzkich ${ }^{28}$. Analiza wpisów wskazuje, że przy ich sporządzaniu korzystano z co najmniej trzech wzorców różniących się nieznacznie konstrukcją, pojedynczymi sformułowaniami czy słowami, co nie miało jednak wpływu na moc i skutki prawne samego $\mathrm{aktu}^{29}$. Czynnościom abrenuncjacji towarzyszyły różne stany faktyczne odnośnie do stanu cywilnego kobiety składającej oświadczenie oraz osób, które posag wypłaciły i do których zrzeczenie było adresowane.

27 Warto porównać przedstawione przez nas dane do liczby odnotowanych w ziemi przemyskiej wyposażeń wychodzących za mąż kobiet w wieku XV. Ze statystyk przedstawionych przez M. Ungeheuera wynika, że w ciągu 32 lat w okresie 1436-1468 odnotowano tam 216 nadań posagów, co daje średnią niemal 7 aktów rocznie. Można domniemywać, że liczba odnoszących się do nich czynności abrenuncjacji była zbliżona, M. Ungeheuer, Stosunki kredytowe w ziemi przemyskiej w połowie XV wieku, Lwów 1929, s. 171-172. Wyniki badań nad tzw. kontraktami lwowskimi wskazują natomiast wprost na liczbę samych aktów abrenuncjacji. W zbliżonym do badanego przez nas okresie, 1676-1686, odnotowano 125 aktów abrenuncjacji (średnio ponad 12 aktów na rok), w latach 1717-1724-129 (średnio 18 na rok), wreszcie w latach 1768-1775 - 63 (średnio 9 na rok). M. Wąsowicz, Kontrakty lwowskie..., s. 84-85, tab. XXX; S. Siegel, Kontrakty lwowskie..., s. 167-168, tab. XXIX; J. Bielecka, Kontrakty lwowskie..., s. 90-91, tab. XXXV.

${ }_{28}$ Formularze służyły za wzorzec przy sporządzaniu pozwów, rekognicji, wpisów lub zawieraniu kontraktów. Funkcjonowały już w wieku XVI, upowszechniły się w XVIII, co było rezultatem ogólnego obniżenia poziomu kultury prawnej, przy jednoczesnym natężeniu formalizmu prawniczego i niedostatku opracowań prawa polskiego. Formularze nabrały więc szczególnego znaczenia i zaczęły spełniać funkcję praktycznej pomocy przy sporządzaniu aktów prawnych, zob. O. Balzer, Kancelarie i akta grodzkie w wieku XVIII, Lwów 1882, s. 21; J. Bielecka, Organizacja i działalność kancelarii ziemskich i grodzkich wielkopolskich XVI-XVIII w., „Archeion” 1954, t. XXII, s. 149-150; W. Witkowski, XVIII-wieczny zbiór formut prawnych grodu lubelskiego, „Rocznik Lubelski” 1973, t. 16, s. 143-145.

${ }_{29}$ Warto jednocześnie zauważyć, że dotyczące abrenuncjacji formuły używane w grodzie przemyskim różniły się od tych, które znane nam są chociażby ze zbiorów autorstwa prawników-praktyków okresu I Rzeczypospolitej, takich jak Szymon Zagórski czy Michał Słoński. Brak jednej uniwersalnej formuły dla czynności abrenuncjacji obowiązującej we wszystkich kancelariach jest jednocześnie dowodem na kształtowanie się tego typu wzorów niezależnie w różnych ośrodkach kancelaryjnych na obszarze całego państwa. Por. S. Zagórski, Formulae juridicae inducendis et conficiendis transactionibus accomodatae legibus Regni conformes ac in castro Lublinensi usitate cura et impensis Simonis Zagorski Vice Regentis castrensis Lublinensis luci publicae traditae. Cum facultate superiorum. Lublini typis S. R. M. Collegii Societatis Jesu, Lublin 1768, s. 50; M. Słoński, Accessoria, statut i konstytucye ..., s. 591-592. Formułę spisana przez Słońskiego przywołał w swoim opracowaniu T. Ostrowski, Prawo cywilne albo szczególne..., t. II, Warszawa 1784, s. 284. Inny XVII-wieczny formularz czynności abrenuncjacji znajduje się w zbiorze Archiwum Riksarkivet w Sztokholmie, zesp. Skoklostersamlingen, sygn. E8603, dostępnym na stronie internetowej: http://www.repcyfr.pl/ dlibra/doccontent?id=844\&dirids=1 (dostęp: 20.04.2018). 
II.2.1. Dane urzędu i osób uczestniczących w czynności abrenuncjacji. Problem asystencji

W części wstępnej zeznania, obok przyjętej zwyczajowo formuły (Comparens personaliter coram officio et actis praesentibus), wpisywano dane urzędu, przed którym sporządzano akt, imię oraz (nie zawsze) nazwisko ${ }^{30}$ kobiety dokonującej abrenuncjacji, jej ojca, względnie obojga rodziców, i osoby asystującej przy składaniu oświadczenia.

Stan cywilny kobiety składającej oświadczenie o zrzeczeniu się praw do rodzinnego majątku decydował o tym, czy złożenie go następowało w asystencji osób trzecich. Było to związane z powszechnym przekonaniem o tak zwanym fragilitas sexus kobiet i ze zwyczajem dokonywania przez żonę czynności prawnych przed sądem (urzędem) w obecności męża ${ }^{31}$. Zbadany materiał źródłowy w pełni potwierdza obowiązywanie tego prawa, także w praktyce czynności abrenuncjacji.

Najczęściej, w 41 przypadkach (87\%), składającej oświadczenie kobiecie asystował mąż, pełniący funkcję małżeńskiego opiekuna. Informacja ta była umieszczana w treści zeznania, np.: Nobilis Nastia Dubrawska [...] Nobilis vero Joannis Niechrebecki consors legitima, cum eiusdem mariti sui, uti tutoris coniugalis personali assistentia ${ }^{32}$.

W wyjątkowych sytuacjach zamężnej kobiecie mógł asystować inny mężczyzna, zazwyczaj członek rodziny. 22 stycznia 1655 roku zeznająca przed aktami Zofia Rudnicka dokonała abrenuncjacji w obecności dwóch bliżej nieokreślonych krewnych: Gnosa Zophia Rudnicka Gnosi Casimiri [nazwisko nieczytelne] ad [fragment nieczytelny] certas legalitates, et rationes iuris assistentiam sibi [fragment nieczytelny] non

30 Zwraca uwagę brak konsekwencji urzędników przyjmujących oświadczenia, którzy wpisywali w treści aktu nazwisko rodowe kobiety lub nazwisko przyjęte po mężu. Stąd zarówno czynność abrenuncjacji Zofii Rudnickiej z domu Zielonki, jak i Anny Lesiowskiej z domu Rudnickiej zapisano w księdze z nagłówkiem „Rudnicka abrenuntiat”, CPAHU, 13, op. 1, 106, p. 113-114., http://www.repcyfr.pl/dlibra/doccontent?id=8362\&dirids=1; CPAHU, 13, op. 1, 105, p. 993, http://www.repcyfr.pl/dlibra/ doccontent?id=7686\&dirids=1 (dostęp: 20.02 .2018$)$.

31 Zwyczaj asystowania kobiecie przez męża w czynnościach dokonywanych przed sądem był rozumiany dwójnasób, jako przywilej lub obowiązek. Jak wskazuje R. Kuratow-Kuratowski, do końca XVII wieku rozpowszechnione było przekonanie o przymusie występowania przez kobiety przed sądem w obecności męskiego opiekuna, z racji „tzw. kruchości płci”. Interpretacja użytego w Statucie Wiślickim zwrotu fragilitas sexus była, zdaniem autora, błędna i należało go rozumieć jako przywilej, a nie przymus. Autor przytacza jednocześnie przykłady różnego rodzaju „zrzeczeń” (resignatio), także pokwitowań przyjęcia posagu, które to czynności mężatki dokonywały samodzielnie. W badanych przez nas aktach z wieku XVII takich przypadków nie odnaleźliśmy. Zob. R. Kuratow-Kuratowski, O zdolności cywilnej kobiet zamężnych w Małopolsce $w$ wieku XIV, ,Studia nad Dziejami Prawa Polskiego Prywatnego” 1917, nr 15, s. 12 (39), 26-27 (54-55); Por. P. Dąbkowski, Prawo prywatne ..., t. I, s. 379; B. Lesiński, Stanowisko kobiety..., s. 178.

32 CPAHU, 13, op. 1, 107, p. 891, http://www.repcyfr.pl/dlibra/doccontent?id=9497\&dirids=1. Formuła ta powszechnie umieszczana była w innych znanych nam formularzach: cum personali ejusdem mariti sui, uti tutoris conjugalis authoritate \& assistentia, T. Ostrowski, Prawo cywilne..., t. II, s. 284; cum personali assistentia et consensu eius mariti sui uti tutori conjugalis sui, Riksarkivet (Stockholm) zespół: Skoklostersamlingen, sygn. E8603, http://www.repcyfr.pl/dlibra/doccontent?id=844\&dirids=1. 
valentis consors legitima, una cum assistentia Gnosorum Jacobi Zdrowski et Philippi Świechowski amicorum ${ }^{33}$ suorum assistentia ${ }^{34}$.

Odnotowaliśmy także jeden przypadek abrenuncjacji dokonanej przez zakonni$\mathrm{cę}^{35}$ (określoną w tekście jako religiosa ac deodicata, professa, monialis) - Krystynę Bolestraszycką ${ }^{36}$, która złożyła oświadczenie o zrzeczeniu się praw spadkowych po ojcu Piotrze Bolestraszyckim ${ }^{37} \mathrm{~W}$ asystencji dwóch sióstr przełożonych - przeoryszy Elżbiety Podłęskiej $^{38}$ (priorisa) i jej zastępczyni Barbary Pogroszowskiej ${ }^{39}$ (subpriorisa) $)^{40} \mathrm{z}$ zakonu benedyktynek ${ }^{41}$.

Ponadto w badanym okresie sporządzono 4 akty (9\%) z czynności zrzeczenia, dokonanych przez wdowy. W treści oświadczenia informacja o wdowieństwie była wyraźnie podawana, jak w przypadku abrenuncjacji z 3 sierpnia 1654 roku: Nobilis Pazia Dobrzańska olim Nobilis Elias Dobrzański filia olim vero Nobilis Andrzej Jaworski consors relicta vidua ${ }^{42}$. Zgodnie z prawem wdowy mogły dokonywać czynności prawnych samodzielnie, bez asysty mężczyzny ${ }^{43}$, i tak też było we wszystkich odnotowanych przypadkach. Jednocześnie warto pokusić się o próbę wyjaśnienia okoliczności abrenuncjacji dokonanych przez wdowy. Jakub Stachel twierdzi, że zdarzało się, iż w związku z nierzadką praktyką wypłacania posagu dopiero po śmierci ojca kobieta w chwili

33 Praktyka sądowa wskazuje na wieloznaczność terminu amicus, który mógł też oznaczać szwagra - męża dalszej krewnej, A. Szymczakowa, Nazewnictwo stosunków rodzinnych w świetle praktyki sądów sieradzkich w 15 wieku, „Studia z Dziejów Państwa i Prawa Polskiego” 1995, t. II, s. 106.

34 CPAHU, 13, op. 1, 107, p. 31-32, http://www.repcyfr.pl/dlibra/doccontent?id=9059\&dirids=1 (dostęp: 20.02.2018).

35 Zaledwie jeden tego typu akt zakonnicy zwraca uwagę, zwłaszcza w zestawieniu z wynikami badań nad wspomnianymi kontraktami lwowskimi. Udział ujawnionych w tamtejszych księgach aktów zrzeczenia dokonanych przez duchowieństwo zakonne (bez rozróżnienia na płeć) kształtował się następująco: w latach 1776-1786 - 23 akty na łączną liczbę 125 wszystkich aktów abrenuncjacji, w latach 1717-1724 - 59/129, w latach 1768-1775 - 21/63. Tak wysoki odsetek abrenuncjacji duchownych zakonnych S. Siegel tłumaczy faktem dokonywania przez jedną osobę często kilku lub kilkunastu abrenuncjacji na rzecz rodziców i każdego z rodzeństwa osobno, M. Wąsowicz, Kontrakty lwowskie..., tab. XXX; S. Siegel, Kontrakty lwowskie..., s. 167, tab. XXIX; J. Bielecka, Kontrakty lwowskie..., tab. XXXV. Wyjaśnienia należy szukać również w zestawieniu żeńskich domów zakonnych okresu I Rzeczypospolitej, z którego wynika, że w Przemyślu funkcjonowały zaledwie 2, podczas gdy we Lwowie 11 klasztorów, M. Borkowska OSB, Zakony żeńskie w Polsce w epoce nowożytnej, Lublin 2010, s. 24.

36 Leksykon zakonnic polskich epoki przedrozbiorowej, t. 3, Wielkie Księstwo Litewskie i Ziemie Ruskie Korony Polskiej, oprac. M. Borkowska OSB, Warszawa 2008, s. 207.

37 Piotr Świętopełk Bolestraszycki h. Lis - podczaszy przemyski (1621-1634), Urzędnicy województwa..., s. 218, 311 .

38 Leksykon zakonnic..., s. 205. W spisie figuruje jako Barbara Podłęska.

39 Leksykon zakonnic..., s. 205. W spisie figuruje jako Barbara Pogroszańska.

40 Przeorysza i podprzeorysza (subprzeorysza) zajmowały w hierarchii klasztornej miejsce zaraz po głównej przełożonej (ksieni), której służyły radą. O skomplikowanym i niejednorodnym nazewnictwie w tytulaturze i ustawach zakonnych: M. Borkowska OSB, Życie codzienne polskich klasztorów żeńskich w XVII-XVIII wieku, Warszawa 1996, s. 208-209.

41 Mowa o założonym w Przemyślu w 1629 r. klasztorze pw. Trójcy Świętej, będącym początkowo filią klasztoru jarosławskiego, który od 1644 r. funkcjonował już jako odrębny nowicjat, M. Borkowska OSB, Zakony żeńskie..., s. 298; CPAHU, 13, op. 1, 107, p. 593-594, http://www.repcyfr.pl/dlibra/ doccontent?id=9343\&dirids=1 (dostęp: 20.02 .2018$)$.

42 CPAHU, 13, op. 1, 106, p. 1097, http://www.repcyfr.pl/dlibra/doccontent?id=8841\&dirids=1 (dostęp: 20.02.2018).

43 A. Winiarz, Polskie prawo majątkowe..., s. 66; B. Lesiński, Stanowisko kobiety..., s. 128.

Artykuły - Articles 
otwarcia spadku po nim była już wdową ${ }^{44}$. Niewykluczone również, że abrenuncjacja nie została dokonana wcześniej przy wyposażeniu kobiety w chwili wstępowania przez nią w związek małżeński bądź też mamy do czynienia z powtórnym zeznaniem, które było wynikiem nacisku krewnych dążących do zabezpieczenia się przed roszczeniami wdowy ponownie wychodzącej za mąż ${ }^{45}$.

$\mathrm{Na}$ marginesie dodajmy, że kwestię asysty starano się w przyszłości uregulować w projekcie Zbioru Praw Andrzeja Zamoyskiego, nakazując, aby wychodzące za mąż kobiety złożyły zeznanie abrenuncjacyjne „,w asystencyi męża albo najbliższych krewnych linii macierzystej i ojczystej, lub kuratora"46.

\section{II.2.2. Ustalenie organu właściwego do przyjęcia zeznania}

Warto zwrócić uwagę, że we wszystkich badanych przez nas przypadkach w składanym oświadczeniu abrenuncjacji mowa jest o odstąpieniu przez kobietę od właściwej jurysdykcji sądowej, którą był sąd ziemski: a terris districtionibus iuribus iurisdictionibus suis quibus propriis et competentibus recedendo. Jednocześnie pojawia się sformułowanie o dokonaniu wpisu do akt grodzkich starościńskich: Praesentis vero iurisdictioni castrensi capitaneali premisliensi quo ad actum praesentem/hunc attinet. Taka praktyka miała charakter powszechny. Z racji coraz rzadziej odbywających się w XVI-XVII wieku roczków ziemskich i związanych z tym, pomimo wprowadzenia instytucji tak zwanego leżenia ksiąg, utrudnień w dokonywaniu wpisów, przy jednoczesnym, stałym dostępie do kancelarii urzędu grodzkiego, było to atrakcyjne rozwiązanie. Pozwalało bowiem praktycznie w każdej chwili dokonać urzędowego zeznania ${ }^{47}$.

\section{II.2.3. Osoby wydające posag i adresaci zeznania rezygnacyjnego}

Najważniejszą część aktu stanowiło oświadczenie o przyjęciu z rąk ojca lub innego członka rodziny (ewentualnie dzierżyciela dóbr) uposażenia $\mathrm{z}$ dóbr ojcowskich i macierzystych, tytułem iure divino et naturali successione concernem ratione dotis et expeditionis, a następnie zrzeczenie się dalszych praw do majątku rodzinnego, wyrażane słowami: abdicat ${ }^{48}$, abrenunciat ${ }^{49}$, renunciat ${ }^{50}$,

44 J. Stachel, Posag jako instytucja ..., s. 201.

45 Przynajmniej w trzech przypadkach, spośród wspomnianych czterech, akt dokonywany był już po śmierci ojca wdowy, a posag wypłacali bracia.

46 Zbiór Praw..., cz. II, art. XIV, § 15.

47 O. Balzer, Kancelarie i akta grodzkie..., s. 5-6; J. Bielecka, Organizacja i działalność..., s. 136; A. Gąsiorowski, Tak zwane prawo wieczności w dawnej Polsce, CPH 1970, t. XXII, z. 2, s. 54-55. Obowiązek złożenia oświadczenia abrenuncjacji w księgach swojej ziemi lub powiatu zapisany został także w Zbiorze Praw Andrzeja Zamoyskiego, cz. II, art. XIV, § 15.

48 CPAHU, 13, op. 1, 103, p. 1571, http://www.repcyfr.pl/dlibra/doccontent?id=4177\&dirids=1 (dostęp: 20.02.2018). W jednym z aktów czasownik abdicat zastąpiono słowem abdicit (CPAHU, 13, op. 1, 104, p. 1020 , http://www.repcyfr.pl/dlibra/doccontent?id=4890\&dirids=1), co być może było skutkiem zastosowania zamiennie czasowników o zbliżonym znaczeniu: abdico, abdicare (wyrzec się) i abdico, abdixi, abdictum (odrzucić, wyrzec się jakiegoś prawa, zrezygnować), zob. J. Sondel, Stownik..., s. 2-3.

49 CPAHU, 13, op. 1, 104, p. 1035, http://www.repcyfr.pl/dlibra/doccontent?id=4899\&dirids=1 (dostęp: 20.02.2018).

50 CPAHU, 13, op. 1, 107, p. 114, http://www.repcyfr.pl/dlibra/doccontent?id=9107\&dirids=1 (dostęp: 20.02.2018) . 
resignat $^{51}$, często $\mathrm{w}$ połączeniu z klauzulą quietat in perpetuum ${ }^{52}$ lub perpetuum incorporando silentium ${ }^{53}$.

W 17 przypadkach aktu abrenuncjacji dokonywała wychodząca za mąż córka, która po otrzymaniu od ojca posagu (niekiedy w treści aktu mowa jest o obojgu rodzicach), składała oświadczenie o rezygnacji z wszelkich roszczeń majątkowych w przyszłości. Przykładem ilustrującym tego rodzaju sytuację jest przypadek Mariny Błazowskiej, z domu Koblańskiej. Pod datą 10 lutego 1652 roku znajdujemy akt, w którym kobieta poświadcza przyjęcie posagu z rąk ojca i matki tytułem dziedziczenia, jednocześnie dokonując na ich rzecz zrzeczenia: Quia sibi per manus Nobilium Stephani Koblanski et Anna Tyskowska parentium suorum pro bonis paternis et maternis se recognoscentem iure divino et naturali successione concernem satisfactum est obquam praestitam satisfactionem bonis iisdem paternis et maternis in rem praefatorum parentium totali et plenarie abdicavit et abrenunciavit prout abdicit et abrenuncjat ${ }^{54}$.

W razie wcześniejszej śmierci ojca i ponownego zamążpójścia matki pannę młodą mógł wyposażyć ojczym, jak w przypadku Zofii Konstancji Czepielowskiej, córki Alberta Rożna, której posag wypłacił Wszebor Jaszowski, drugi mąż jej matki - Zofii Baranowskiej $j^{55}$.

Najczęściej jednak nieżyjącego ojca zastępował brat lub bracia ${ }^{56}$, co odnotowaliśmy w 21 przypadkach. Między innymi w zeznanym 29 marca 1651 roku akcie abrenuncjacji Marusi Wołoszynowskiej, córki zmarłego Konstantego Uniatyckiego, czytamy: Quia sibi per manus Nobilis Stephani Uniatycki fratris sui germani pro bonis paternis et maternis se recognoscentem post parentes suos iure divino et naturali successione [...] in rem et manus ejusdem fratris sui totaliter et plenarie abdicavit et abrenunciavit $t^{57} . \mathrm{Z}$ oświadczenia Marianny Bartkowskiej, złożonego 25 maja 1652 roku, wynika, że wyposażenia dokonali dwaj bracia: Michał i Mikołaj ${ }^{58}$, zaś według zeznania Heleny Włodkowej z 18 marca 1655 roku posag wydał jej brat Jan Wysoczański, działając w imieniu swoim oraz pozostałych, nieletnich braci: Stanisława, Tomasza i Stefana ${ }^{59}$.

${ }^{51}$ CPAHU, 13, op. 1, 107, p. 1535, http://www.repcyfr.pl/dlibra/doccontent?id=9826\&dirids=1 (dostęp: 20.02.2018).

${ }_{52}$ CPAHU, 13, op. 1, 108, p. 529, http://www.repcyfr.pl/dlibra/doccontent?id=10046\&dirids=1 (dostęp: 20.02.2018).

${ }_{53}$ CPAHU, 13, op. 1, 107, p. 1371, http://www.repcyfr.pl/dlibra/doccontent?id=9741\&dirids=1 (dostęp: 20.02.2018).

${ }^{54}$ CPAHU, 13, op. 1, 104, p. 1020, http://www.repcyfr.pl/dlibra/doccontent?id=4890\&dirids=1 (dostęp: 20.02.2018).

${ }_{55}$ CPAHU, 13, op. 1,105 , p. 488-489, http://www.repcyfr.pl/dlibra/doccontent?id=7414\&dirids=1 (dostęp: 20.02.2018).

${ }_{56}$ Zob. J. Pielas, Majątkowe zabezpieczenie sióstr $w$ szlacheckich działach spadkowych $w$ Koronie $w$ XVII wieku [w:] Per mulierem... Kobieta $w$ dawnej Polsce $-w$ średniowieczu $i$ w dobie staropolskiej, red. K. Justyniarska-Chojak, S. Konarska-Zimnicka, Warszawa 2012, s. 343-356.

57 CPAHU, 13, op. 1, 104, p. 197, http://www.repcyfr.pl/dlibra/doccontent?id=4466\&dirids=1 (dostęp: 20.02.2018).

58 CPAHU, 13, op. 1, 104, p. 1740, http://www.repcyfr.pl/dlibra/doccontent?id=8012\&dirids=1 (dostęp: 20.02.2018).

${ }_{59}$ CPAHU, 13, op. 1,107 , p. 865, http://www.repcyfr.pl/dlibra/doccontent?id=9479\&dirids=1 (dostęp: 20.02.2018).

Artykuły - Articles 
W akcie z 13 grudnia 1651 roku podano informację o wyposażeniu Katarzyny, żony Felicjana Zakliki, wspólnie przez matkę i brata ${ }^{60}$ : per manus Generosorum suprascripta Hedvigis de Chodoristaw Ostrowska parentis suis tum Christopheri de Ostrów Ostrowski fratris sui germani ${ }^{61}$.

Natomiast $\mathrm{w}$ dwóch przypadkach jako jedyna osoba wypłacająca posag wskazana została Anna z Wisłockich, wdowa po Andrzeju Błazowskim. 7 lutego 1652 roku ich córki: Marina Turzańska i Katarzyna Stupnicka, złożyły kolejno zeznania abrenuncjacji, w których zeznały: Quia sibi recognoscenti per manus praefata Generosa Anna Błazowska parentis suae pro bonis paternis et maternis se recognoscentem iure divino et naturali successione concernem totaliter et plenarie satisfactum est. W obu aktach, z wyraźnym podkreśleniem liczby pojedynczej, rezygnacja złożona została in rem/in manus prefatea parentis ${ }^{62}$.

Dowodem na wypłatę posagu przez dalszych krewnych bocznych jest wpis datowany na 20 maja 1651 roku, z którego wynika, że Nastazja Kulczycka otrzymała posag z rąk swoich bratanków, Iwana i Ilka, synów jej zmarłych braci - Jacka i Andrzeja Straszowskich. Do nich jednocześnie, jako aktualnych posiadaczy dóbr rodzinnych, adresowany był akt zrzeczenia: in rem eorum filiastrorum suorum totaliter et plenarie abdicavit et abrenunciavit ${ }^{63}$.

Interesujące wydają się dwa przypadki sióstr Magdaleny i Anny z Dreznerów. W złożonych przez nie oświadczeniach z 1654 i 1655 roku jako osoba wypłacająca im posag, w zastępstwie zmarłych rodziców, wskazany został Sebastian Charczowski. Same akty abrenuncjacji nie wyjaśniają co prawda, jaka relacja łączyła go z wychodzącymi za mąż kobietami ${ }^{64}$, lecz pewną wskazówką może być inny zachowany w księgach dokument, z którego wynika, że Charczowski nabył od brata Magdaleny i Anny - Alberta, dobra rodzinne Dreznerów, przez co prawdopodobnie przejął obowiązek wyposażenia obu sióstr ${ }^{65}$.

W dwóch przypadkach nie wskazano, kto wypłacił kobiecie posag.

60 Przypadki partycypowania przez matkę wraz z synami w wypłacie posagu znane są także $\mathrm{z}$ innych źródeł, J. Pielas, Majątkowe zabezpieczenie sióstr..., s. 350.

${ }_{61}$ CPAHU, 13, op. 1, 104, p. 757, http://www.repcyfr.pl/dlibra/doccontent?id=4743\&dirids=1 (dostęp: 20.02.2018).

${ }^{62}$ CPAHU, 13, op. 1, 104, p. 870, http://www.repcyfr.pl/dlibra/doccontent?id=4805\&dirids=1; CPAHU, 13, op. 1, 104, p. 870-871, http://www.repcyfr.pl/dlibra/doccontent?id=4806\&dirids=1 (dostęp: 20.02.2018).

63 CPAHU, 13, op. 1, 104, p. 406, http://www.repcyfr.pl/dlibra/doccontent?id=4571\&dirids=1 (dostęp: 20.02.2018).

${ }^{64}$ CPAHU, 13, op. 1, 106, p. 117, http://www.repcyfr.pl/dlibra/doccontent?id=8365\&dirids=1; CPAHU, 13, op. 1, 107, p. 337, http://www.repcyfr.pl/dlibra/doccontent?id=9221\&dirids=1 (dostęp: 20.02.2018).

65 CPAHU, 13, op. 1, 106, p. 259-261, http:/www.repcyfr.pl/dlibra/doccontent?id=8435\&dirids=1 (dostęp: 20.02.2018). 


\section{II.3. Akty prawne towarzyszące czynności abrenuncjacji od majątku rodzicielskiego}

Spisanie aktu abrenuncjacji jako konsekwencja wypłaty posagu pozostawało w ścisłym związku z innymi czynnościami prawnymi dokonywanymi przez małżonków przed księgami ziemskimi i grodzkimi.

Rezygnację z praw do rodzinnego majątku poprzedzał zazwyczaj dokonywany przez męża zapis oprawy posagu wniesionego przez żonę. $Z$ badanych ksiąg urzędu grodzkiego przemyskiego wynika, że oba akty z reguły - tak było w 25 przypadkach - sporządzano jednego dnia, co zapewne miało swoje praktyczne uzasadnienie. Przede wszystkim jednak podyktowane było względami bezpieczeństwa samej kobiety, która składała oświadczenia o abrenuncjacji dopiero po oprawieniu posagu przez męża. Nierzadko towarzyszyło temu również zawieranie przez małżonków umów dożywocia. Odnotowaliśmy 16 takich aktów. Nie licząc abrenuncjacji dokonanych bez asystencji męża, w 4 przypadkach na 10 małżonkowie tego samego dnia decydowali się na podpisanie umowy dożywocia ${ }^{66}$, we wszystkich zresztą przypadkach dożywocia o charakterze wzajemnym ${ }^{67}$. Wyraźnie więc zarysowuje się określony porządek czynności, który obejmował kolejno: wyposażenie kobiety przez osobę zobowiązaną, reformację posagu, jego kwitowanie i rezygnację z praw do majątku rodziców, wreszcie, umowę dożywocia małżeńskiego.

\section{II.4. Inne rodzaje aktów abrenuncjacji}

$\mathrm{Z}$ badanych dokumentów wynika, że terminem abrenuncjacji posługiwano się w księgach sądowych nie tylko w odniesieniu do czynności zrzeczenia się praw do majątku rodzinnego przez wyposażane kobiety, ale także innych zeznań o charakterze rezygnacyjnym.

8 lutego 1652 roku wdowa po Wasylu Lityńskim - Katarzyna z Szeptyc - złożyła oświadczenie o rezygnacji z prawa do dożywocia małżeńskiego (advitalitium). Jej zeznanie, opisane w aktach jako abrenuncjacja zostało poprzedzone urzędowym pokwitowaniem przyjęcia, tytułem prostego długu, kwoty czterech tysięcy złotych polskich od syna zmarłego męża - Marka Lityńskiego ${ }^{68}$. W następstwie wdowa odstąpiła od przysłu-

${ }^{66}$ Umowę dożywocia wzajemnego podpisali między innymi: Katarzyna i Felicjan Zaklika, Zofia i Władysław Rudnicki, Anna i Mikołaj Lesiowscy, CPAHU, 13, op. 1, 104, p. 755-757, http://www.repcyfr.pl/ dlibra/doccontent?id=4742\&dirids=1 (dostęp: 20.02.2018); CPAHU, 13, op. 1, 105, p. 992-993, http://www. repcyfr.pl/dlibra/doccontent?id=7685\&dirids=1 (dostęp: 20.02.2018); CPAHU, 13, op. 1, 106, p. 115-116, http://www.repcyfr.pl/dlibra/doccontent?id=8364\&dirids=1 (dostęp: 20.02.2018).

${ }_{67}$ Zob. M. Głuszak, Advitalitas simplex $i$ advitalitas mutua w polskim prawie ziemskim, „Krakowskie Studia z Historii Państwa i Prawa” 2018, t. 11, z. 2.

68 CPAHU, 13, op. 1, 104, p. 892, http://www.repcyfr.pl/dlibra/doccontent?id=4819\&dirids=1 (dostęp: 20.02.2018).

Artykuły - Articles 
gującego jej na mocy umowy prawa dożywocia na mężowskim majątku ${ }^{69}$. Podobny akt abrenuncjacji po śmierci męża złożyła 7 lipca 1654 roku Anna Marchocka ${ }^{70}$.

27 marca 1657 roku zeznanie abrenuncjacji złożyło wspólnie rodzeństwo Iwan i Ewa olim vero Nobilis Waśko Raszkowce Koblański cum olim Nobili Marushia Hoszowska procreati filij et filia. W tym przypadku akt zrzeczenia dotyczył dóbr po zmarłej matce. Jak wynika z jego treści, rodzeństwo zostało zaspokojone przez Stanisława Hoszowskiego (prawdopodobnie wuja) i złożyło oświadczenie o rezygnacji z praw do majątku rodziny matki ${ }^{71}$. Niestety zaledwie jeden odnotowany przez nas przypadek abrenuncjacji dokonanej wspólnie przez siostrę i brata nie pozwala nam zająć jednoznacznego stanowiska odnośnie do charakteru takiego zrzeczenia.

\section{Podsumowanie}

Czynność abrenuncjacji nie stanowiła jak dotąd przedmiotu szczególnego zainteresowania badaczy, a wspominano o niej wyłącznie przy okazji prac traktujących o zasadach wyposażania kobiet opuszczających dom rodzinny. Tymczasem w świetle przeprowadzonych badań należy stwierdzić, że akt ów był powszechnie praktykowany, ściśle związany ze zwyczajem wyposażania córek przez osoby, w których posiadaniu znajdowały się rodzinne dobra - ojca, względnie rodzonych braci lub innych męskich (z wyjątkami) krewnych.

Oświadczenia wpisywane były do akt urzędowych i miały stanowić dla każdoczesnego dzierżyciela rodzinnego majątku zabezpieczenie przed finansowymi roszczeniami, nie tylko ze strony samych córek i sióstr, ale również ich mężów, obecnych zazwyczaj przy składanym zeznaniu.

Czynność abrenuncjacji stanowiła, po akcie wypłaty posagu i jego oprawy, ostatni etap procesu rozliczeń majątkowych między opuszczającą dom rodzinny córką, względnie siostrą, a krewnymi pozostającymi na dobrach rodowych, wpisując się w ugruntowaną w polskim prawie ziemskim zasadę ograniczającą prawa spadkowe kobiet, wyłącznie do wysokości otrzymywanego posagu.

Niestety nie udało się dotrzeć do dokumentów potwierdzających praktykę melioracji posagu, roszczeń o zwiększenie jego wysokości, pomimo wcześniej złożonego aktu zrzeczenia $^{72}$. Nie możemy więc stwierdzić, czy i w jakiej skali zjawisko to występowało, co powinno stanowić zachętę do dalszych poszukiwań archiwalnych i badań nad tym zagadnieniem.

Powyższe rozważania oparte na niewielkim materiale źródłowym mają charakter przyczynkowy. Wobec braku kompleksowego opracowania obejmującego problematy-

${ }^{69}$ CPAHU, 13, op. 1,104 , p. $892-893$, http://www.repcyfr.pl/dlibra/doccontent?id=4820\&dirids=1 (dostęp: 20.02.2018).

70 CPAHU, 13, op. 1, 106, p. 1010-1011, http://www.repcyfr.pl/dlibra/doccontent?id=8797\&dirids=1 (dostęp: 20.02.2018).

${ }_{71}$ CPAHU, 13, op. 1, 108, p. 805-806, http://www.repcyfr.pl/dlibra/doccontent?id=10134\&dirids=1 (dostęp: 20.02.2018).

${ }_{72}$ Przypadki spraw o meliorację posagu przytacza A. Penkała, Przeciw prawu ..., s. 107-116.

Artykuły - Articles 
kę rodzinnego prawa majątkowego okresu I Rzeczypospolitej mogą jednak stanowić punkt wyjścia do kontynuacji prac i okazać się przydatne w badaniach poświęconych tej materii prawa prywatnego.

\section{Bibliografia}

Źródła rękopiśmienne w zasobach internetowych

Archiwum Riksarkivet w Sztokholmie, zesp. Skoklostersamlingen, sygn. E8603, http://www.repcyfr.pl/dlibra/doccontent?id=844\&dirids=1 (dostęp: 20.04 .2018$)$.

Centralne Państwowe Archiwum Historyczne Ukrainy, zesp. 13, op. 1. sygn. 104, 105, 106, 107 , 108, http://www.repcyfr.pl/dlibra (dostęp: 20.04.2018).

\section{Źródła wydane}

Czacki T., O litewskich i polskich prawach, o ich duchu, źródłach, zwiazku i o rzeczach zawartych w pierwszem Statucie dla Litwy 1529 roku wydanem, t. II, Warszawa 1801.

Ostrowski T., Prawo cywilne albo szczególne narodu polskiego, t. I-II, Warszawa 1784.

Słoński M., Accessoria, statut i konstytucye Czaradzkiego, Ladowskiego y suplementu J. O. Xcia Jegomości Biskupa Krakowskiego w Pospolitości a najbardziej co do procesu potrzebniejszego tudzież Formularze tranzakcyi niektórych przez Jmci Pana Michała Słońskiego Vicegerenta Łukowskiego S. G. zebrane, Lwów 1765.

Statuta Ducatus Mazoviae [w:] Ius Polonicum codicibus veteribus manuscriptis et editionibus quibusque collatis, wyd. J.W. Bandtkie, Warszawa 1831.

Statuta inclyti Regni Poloni[a]e recens recognita emendata, wyd. Hieronim Wietor, Kraków 1532.

Statuty Kazimierza Wielkiego, oprac. O. Balzer, Poznań 1947.

Umiastowski T., Sądowy proces czyli sposób prawowania się w Trybunale $i$ wszystkich subselliach W. Xięstwa Litewskiego..., wyd. V, Grodno 1782.

Volumina Legum, t. II, VII, oprac. J. Ohryzko, Petersburg 1859.

Zagórski S., Formulae juridicae inducendis et conficiendis transactionibus accomodatae legibus Regni conformes ac in castro Lublinensi usitate cura et impensis Simonis Zagorski Vice Regentis castrensis Lublinensis luci publicae traditae. Cum facultate superiorum. Lublini typis S.R.M. Collegii Societatis Jesu, Lublin 1768.

Zbiór Praw Sadowych na mocy konstytucyi roku 1776 przez J. W. Andrzeia Zamoyskiego ex-kanclerza koronnego, kawalera Orderu Orta Białego ułożony i na seym roku 1778 podany, Warszawa 1778.

Zbiór rezolucji interpretacyjnych Rady Nieustajacej z lat 1786-1788, oprac. M. Głuszak, Łódź 2014.

\section{Opracowania}

Adamus J., O prawie dziedziczenia nieruchomości przez kobiety w najdawniejszym prawie polskim, CPH, t. XI, z. 1, 1959.

Balzer O., Kancelarie i akta grodzkie w wieku XVIII, Lwów 1882.

Artykuły - Articles 
Bandtkie J.W., Prawo prywatne polskie napisane i wyktadane przed r. $1830 \mathrm{w}$ b. Warszawskim Aleksandryjskim Uniwersytecie, Warszawa 1851.

Bardach J., Historia państwa i prawa Polski, t. I, Warszawa 1965.

Bielecka J., Kontrakty lwowskie w latach 1768-1775, Poznań 1948.

Bielecka J., Organizacja i działalność kancelarii ziemskich i grodzkich wielkopolskich XVIXVIII w., „Archeion” 1954, t. XXII.

Borkowska M. OSB, Zakony żeńskie w Polsce w epoce nowożytnej, Lublin 2010.

Borkowska M. OSB, Życie codzienne polskich klasztorów żeńskich w XVII-XVIII wieku, Warszawa 1996.

Burzyński P., Prawo polskie prywatne, t. II, Kraków 1871.

Dąbkowski P., Prawo prywatne polskie, t. I, Lwów 1910.

Dunin K., Dawne mazowieckie prawo, Warszawa 1880.

Dutkiewicz W., Stowo o stosunkach majatkowych między matżonkami i o prawie zwyczajowym polskim, Warszawa 1877.

Dutkiewicz W., Zbiór Praw Sądowych przez ex-kanclerza Andrzeja Ordynata Zamoyskiego ułożony i w roku 1778 drukiem ogłoszony, a teraz przedrukowany, z domieszczeniem źródeł i uwag tak prawoznawczych jak i prawodawczych, sporządzonych przez Walentego Dutkiewicza, Warszawa 1874.

Encyklopedia staropolska ilustrowana, t. I, Warszawa 1900.

Gąsiorowski A., Tak zwane prawo wieczności w dawnej Polsce, CPH 1970, t. XXII, z. 2.

Gloger Z., Encyklopedia staropolska ilustrowana, t. I, Warszawa 1900.

Głuszak M., Advitalitas simplex $i$ advitalitas mutua w polskim prawie ziemskim, „Krakowskie Studia z Historii Państwa i Prawa” 2018, t. 11, z. 2.

Kapras J., Manželské právo majetkové dle českého práva zemského, Praha 1908.

Koczerska M., Rodzina szlachecka w Polsce późnego średniowiecza, Warszawa 1975.

Koranyi K., Podstawy średniowiecznego prawa spadkowego, Lwów 1930.

Korowicki A., Proces cywilny litewski, Wilno 1826.

Kuratow-Kuratowski R., O zdolności cywilnej kobiet zamężnych $w$ Małopolsce $w$ wieku XIV, „Studia nad Dziejami Prawa Polskiego Prywatnego” 1917, nr 15.

Leksykon zakonnic polskich epoki przedrozbiorowej, t. 3, Wielkie Księstwo Litewskie i Ziemie Ruskie Korony Polskiej, oprac. M. Borkowska OSB, Warszawa 2008.

Lesiński B., Stanowisko kobiety w polskim prawie ziemskim do połowy XV wieku, Wrocław 1956.

Matusiak S., Wiano i posag, Warszawa 1912.

Matuszewski J., Aqua abrenuntiationis. Studium z średniowiecznego prawa prywatnego, CPH 1952, t. IV.

Michalski J., Studia nad reforma sądownictwa i prawa sądowego w XVIII w., Wrocław-Warszawa 1958.

Orgelbrand M., Słownik języka polskiego, cz. I, Wilno 1861.

Penkała A., Panieńskie ochędóstwo. Kwestie posagowe $i$ wienne $w$ malżeństwach szlachty województwa krakowskiego w czasach saskich, Kraków 2016.

Penkała A., Przeciw prawu, tradycji i obyczajowi. Sprawy procesowe szlacheckich matzeństw w księgach sąów grodzkich z terenu województwa krakowskiego w czasach saskich, Kraków 2017.

Pielas J., Majątkowe zabezpieczenie sióstr w szlacheckich działach spadkowych $w$ Koronie w XVII wieku [w:] Per mulierem... Kobieta $w$ dawnej Polsce $-w$ średniowieczu $i$ w dobie staropolskiej, red. K. Justyniarska-Chojak, S. Konarska-Zimnicka, Warszawa 2012.

Plezia M., Słownik łacińsko-polski, t. I, Warszawa 1959.

Popiołek B., Rodzina szlachecka w świetle testamentów XVII-XVIII wieku [w:] Rodzina i gospodarstwo domowe na ziemiach polskich $w X V$-XX wieku. Struktury demograficzne, spoteczne $i$ gospodarcze, red. C. Kuklo, Warszawa 2008. 
Roman S., Stanowisko majątkowe wdowy w średniowiecznym prawie polskim, CPH 1953, t. V.

Seredyka J., Madaliński Marcin, PSB, t. XIX, Kraków 1974.

Siegel S., Kontrakty lwowskie w latach 1717-1724, Lwów 1935.

Sondel J., Stownik łacińsko-polski dla prawników i historyków, Kraków 2005.

Spasowicz W., O stosunkach majątkowych między matżonkami wedle dawnego prawa polskiego [w:] Pisma, t. IV, Petersburg 1892.

Stachel J., Posag jako instytucja prawa spadkowego [w:] Pamiętnik trzydziestolecia pracy naukowej prof. Przemysława Dąbkowskiego, Lwów 1937.

Szczepankowska I., Język prawny I Rzeczypospolitej w „,Zbiorze praw sadowych” Andrzeja Zamoyskiego, t. I, Pojęcia prawne, Białystok 2004.

Szymczakowa A., Nazewnictwo stosunków rodzinnych w świetle praktyki sądów sieradzkich w 15 wieku, „Studia z Dziejów Państwa i Prawa Polskiego” 1995, t. II.

Ungeheuer M., Stosunki kredytowe w ziemi przemyskiej w połowie XV wieku, Lwów 1929.

Uruszczak W., Uwagi o polskiej rodzinie szlacheckiej w późnym średniowieczu, CPH 1976, t. XXVIII, z. 2.

Urzędnicy województwa ruskiego XIV-XVIII wieku. Spisy, oprac. K. Przyboś, red. A. Gąsiorowski, Kórnik 1987.

Wąsowicz M., Kontrakty lwowskie w latach 1676-1686, Lwów 1935.

Winiarz A., Polskie prawo dziedziczenia kobiet w wiekach średnich, KH 1896, t. X.

Winiarz A., Polskie prawo majątkowe matżenskie w wiekach średnich, Kraków 1898.

Witkowski W., XVIII-wieczny zbiór formut prawnych grodu lubelskiego, „Rocznik Lubelski” 1973, t. 16.

Zielińska T., Rozważania nad kwestia wyposażania szlachcianek $w$ Wielkim Księstwie Litewskim w XVIII stuleciu, KH 1989, R. 96, z. 1-2. 